\title{
Development and Application of Probabilistic Performance Index for Ranking N-1 Contingencies
}

\author{
Saidu Y. Musa, Monday A. Madaki, and Jinkai Haruna
}

\begin{abstract}
Contingency analysis and ranking are important tasks in modern electrical power systems which aim at keeping the power system secure, reliable, and stable. $\mathrm{N}-1$ contingency is the loss of any one component of power system and is obviously the most frequent contingency in power system. Contingency ranking has most often been done using deterministic indices which can be either active power performance index $(\mathrm{PIP})$, voltage performance index (PIv) or the overall performance index (PI). Power system contingencies are ranked based on the calculated Performance index for each contingency. Ranking is from the contingency with the highest performance index first and proceeds in a descending manner which corresponds to the most severe to the least severe contingency. Due to the fact that Contingencies are unpredictable events, researchers of recent have suggested the inclusion of the probability of the occurrence of a contingency in its ranking index. This makes the index probabilistic. In this work, the development and application of probabilistic performance index for ranking $\mathrm{N}$ 1 contingencies is considered. It is illustrated with a case study.
\end{abstract}

Key words - Contingency, Contingency ranking, N-1 Contingency, Probabilistic Performance Index, State Probability.

\section{INTRODUCTION ${ }^{1}$}

Contingency in electrical power system are unpredictable events that are detrimental to the power system operation. It refers to outage of system components which is possible but cannot be predicted with certainty. A contingency is basically an outage of a generator, transformer and or line, and its effects are monitored with precise security limits [1]. ' $\mathrm{N}-1$ ' contingency is the loss of any one component of power system (line, transformer, generator etc.). Unarguably, N-1 contingency is the most frequent in power systems. A power system design requirement is to satisfy $\mathrm{N}-1$ operation, that is, when any one of its generators, transformers or transmission lines fails, the system operation criteria remain within acceptable limits. [xi fang yang] However, as the operating state of the power system changes such as loss of generator, loss of a transmission line, loss of a transformer or a load, these changes may cause equipment overloads or unacceptable voltage levels [2].

Contingencies pose a serious problem to power system networks especially over stretched networks where the installed facilities are almost fully utilized. Contingency in a

Submitted on July 01, 2021.

Published on July 22, 2021.

Saidu Y. Musa, Department of Electrical/Electronics Engineering, Modibbo Adama University of Technology, Yola, Adamawa, Nigeria.

(e-mail: saiduymusa ${ }^{\circledR}$ mautech.edu.ng)

Monday A. Madaki, Department of Electrical/Electronics Engineering, Modibbo Adama University of Technology, Yola, Adamawa, Nigeria.

(e-mail: mendus4real40@yahoo.com) power system can lead to reduced system reliability and affects, negatively, system security and continuity. It can also lead to instability of entire power system and ultimately total system collapse. Because of its negative effect to smooth power system operation, severity and types of contingencies are often studied even before they occur to know which type require much preventive measures to be taken. The contingencies are often arranged (ranked) according to severity from the most severe to the least severe.

The most adopted procedure for contingency analysis and ranking is using Newton Raphson power flow solution and is carried out in the following steps [3].

Step 1: Read system's line data and bus data.

Step 2: Perform pre contingency power flow analysis to obtain base case values.

Step 3: Simulate a contingency by removing the component on outage.

Step 4: Run power flow analysis for this particular outage and calculate the active power flow in the remaining branches of the network.

Step 5: Calculate the active power performance index $\left(\mathrm{PI}_{\mathrm{P}}\right)$ which indicates the degree of line overloads and the voltage performance index $\left(\mathrm{PI}_{\mathrm{V}}\right)$ which indicates the voltage limit violation at all the load buses due to the contingency [4].

Step 6: The system's overall performance index is obtained by adding $\mathrm{PI}_{\mathrm{P}}$ and $\mathrm{PI}_{V}$ for each line outage [3]. The $\mathrm{PI}_{\mathrm{P}}$ and $\mathrm{PI}_{V}$ are calculated as in equations (1) and (3) respectively [1], [3], [5].

$P I_{P}=\sum_{i=1}^{N_{L}} \frac{w}{2 z}\left(\frac{P_{i}}{P_{i}^{\max }}\right)^{2 z}$

Where

$\mathrm{P}_{\mathrm{i}}$ - the post contingency power flowing in the $i^{\text {th }}$ line;

$N_{L}$ - Number of the transmission lines in the power system;

$w$ - Real non-negative weighting factor $(=1)$;

$z$-Order of Exponent $(=1)$

$P_{i}^{\max }=\frac{\left|V_{i}\right|\left|V_{j}\right|}{X_{i j}}$

Jinkai Haruna, Department of Electrical/Electronics Engineering, Modibbo Adama University of Technology, Yola, Adamawa, Nigeria.

(e-mail: jinkaiharuna ${ }^{\circledR}$ gmail.com) 
where

$V_{i}$-Pre contingency voltage at bus $\mathrm{i}$;

$V_{j}$ - Pre contingency voltage at bus $\mathrm{j}$;

$X_{i j}$ - Reactance of line connecting buses $\mathrm{i}$ and $\mathrm{j}$.

$P I_{V i}=\sum_{i=1}^{N_{B}} \frac{w_{i}}{2 z}\left\{\left(\left|V_{i}\right|-\left|V_{i}^{s p}\right|\right) / \Delta V_{i}^{\max }\right\}^{2 z}$

where

$\left|V_{i}\right|$-Voltage magnitude at $\mathrm{i}^{\text {th }}$ bus;

$\left|V_{i}^{s p}\right|$-Specified (rated) voltage magnitude at the $\mathrm{i}^{\text {th }}$ bus;

$\Delta V_{i}^{\max }$ - Maximum deviation in the voltage;

$z$ - Order of Exponent (=1);

$N_{B}$ - Number of buses in the system;

$w$ - Real non-negative weighting factor $(=1) /$

The voltage deviation limit can be calculated by taking average value of minimum and maximum allowable voltages at a particular bus. The maximum voltage limit is 1.05 p.u and minimum voltage limit is 0.95 p.u since $\pm 5 \%$ deviation in voltage is allowed [5].

Step 7: Repeat Steps 3 to 6 to obtain the PI for all other possible contingencies.

Step 8: Rank the contingencies based on the values of the performance indices obtained.

The fact that contingencies are probabilistic makes their probability of occurrence an important factor to be considered when ranking them. Nowadays, the deterministic indices are used along with the probability of occurrence in ranking contingencies. The combination of the probability of occurrence and a deterministic index results in a probabilistic index. If the deterministic index (PI) is multiplied by the probability of contingency occurrence, the resulting PI will be probabilistic, rather than deterministic, which is more realistic since most of system failures are probabilistic in nature. The probabilistic index which is called "Expected Performance Index, $\epsilon$ PI, in [6] is formulated as:

$\epsilon P I_{i}=P I_{i} . P_{i}$

where

$\epsilon \mathrm{PI}$ is probabilistic performance index (PPI).

$P_{i}$ is probability of occurrence of contingency.

$\mathrm{PI}$ is the deterministic overall index.

In another related work [7], PPI is expressed as:

$P P I=\sum_{j=1}^{N_{C}} k=1$ to $N_{B}\left(\frac{\omega}{Y}\right)\left(\frac{L_{k j} F_{j}}{L_{\max }}\right)^{Y}$

where

$\omega$-Real non-negative weighting factor;

$n$-Order of exponent;

$\mathrm{L}_{\max }$ - Maximum load curtailed;

$\mathrm{N}_{\mathrm{B}}$ - Number of buses;

$\mathrm{N}_{\mathrm{C}}$ - Number of contingencies;

$\mathrm{L}_{\mathrm{kj}}-\mathrm{MW}$ curtailed at bus $\mathrm{k}$ for contingency $\mathrm{j}$;

$\mathrm{L}_{\max }$ - Maximum load curtailed;

$F_{j}-$ Frequency of failure for contingency $j$.
$F_{j}=P_{j} *($ transition rates $)$

where

$P_{j}-$ State probabilities.

It is observed from (4) through (6) that the probability of any contingency state is required for PPI formulation. In this work, the contingency state probabilities are computed for $\mathrm{N}-1$ contingencies and the PPI is formulated as in (4). The procedure is illustrated with a case study.

\section{MEthodOLOGY}

The required bus and line data were obtained from the operational records of the Transmission Company of Nigeria (TCN) [8]. The data are presented in an appendix. All possible contingencies are first of all analyzed using Newton Raphson method to find out if there are extremely severe contingencies and if there are others that do not affect system's stable operation. The analysis and selection are carried out as illustrated for line contingencies in the flow chart of Fig. 1.

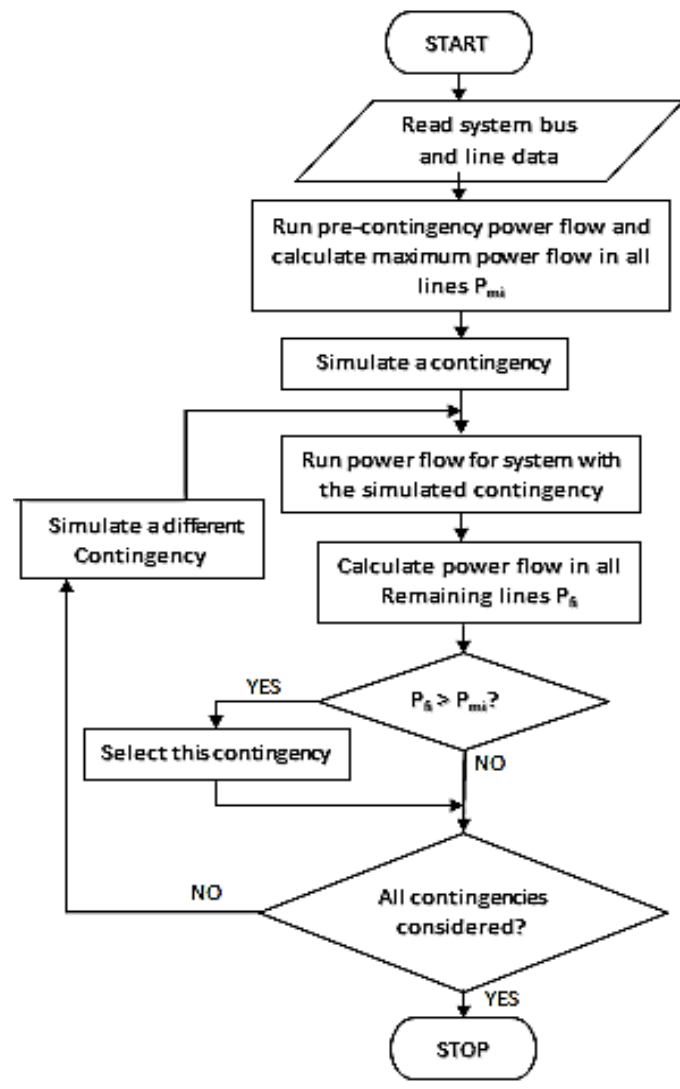

Fig. 1. Flow chart for severe contingency selection.

Outage data which should necessarily include the forced outage hours $(\mathrm{FOH})$ and the service hours $(\mathrm{SH})$ are gathered for the selected power system components with contingencies to be ranked. The FOH is the number of hours within time duration, usually one year, during which the component is unfit to operate due to its own fault. SH is the number of hours in the time period during which the component is either operating or 
capable of operating. Partial operating times are converted to equivalent full $\mathrm{SH}$ or $\mathrm{FOH}$ [9].

Using gathered outage data, availability of every component is computed as [10]:

$a v_{k}=\frac{S H_{k}}{\mathrm{FOH}_{k}+S H_{k}}$

where $a v_{k}$ is the availability of component k. $S H_{k}$ and $\mathrm{FOH}_{k}$ are the service hours and forced outage hours of component $\mathrm{k}$.

In power system reliability assessment, it is always assumed that component failures are independent events. That being the case, system state probabilities may be calculated as the product of component state probabilities. From the availability (av) and unavailability $\left(1-\mathrm{a}_{\mathrm{v}}\right)$ for components (generators, transformers, transmission lines etc.), state probabilities for $\mathrm{N}$ 1 failure are computed as [11]:

$P_{j}=\left(1-(a v)_{j}\right) \prod_{\substack{k=1 \\ k \neq j}}^{N_{a}}(a v)_{k}$

where $P_{j}$ - Probability of occurrence of the $j^{\text {th }}$ contingency; $(\text { av })_{\text {I }}$ - availability of line I;

$\mathrm{N}_{\mathrm{a}}$ - Number of available lines.

The Probabilistic Performance Index for N-1 Contingency ranking (PPIN-1), formulated as in equation (4) is:

$P P I(N-1)_{j}=P_{j} P I_{j}$

where

PPI $(N-1)_{j}$ - Probabilistic performance index for $j^{\text {th }} \mathrm{N}-1$ contingency;

$P_{j}$ - Probability of being in contingency state $\mathrm{j}$;

$P I_{J}$ - Deterministic performance index for $j^{\text {th }}$ contingency.

After obtaining the PPI (N-1) for all contingencies, ranking is done starting with the one with the highest PPI $(\mathrm{N}-1)$ ranked first and then arranged in descending order of indices, quantifying the severity of contingencies from the most to the least severe.

\section{CASE Study}

The case study is $330 \mathrm{kV}$ transmission network of the Nigerian National Electric Power System (NNEPS). The network has 33 buses and 41 transmission lines. Nine (9) of the buses are generator buses and the rest are load buses. In this work, Egbin GS has been chosen as the slack bus and only N1 transmission line contingencies are considered for illustration. The buses and lines and their data as well as the system's one-line diagram are given in an appendix.

\section{RESULT AND CONCLUSION}

Every possible line contingency is first analyzed to determine its severity on the power system operation. The analysis is to simulate every possible contingency one after another and computing the active power performance index, the Voltage Performance index and the overall performance index for each simulated contingency using Newton Raphson method. The results are given in Table I.

As observed from Table I, after the contingency screening process, eighteen out of the forty-one possible line contingencies are found to cause instability in the network while the remaining twenty-three have varying degrees of adverse effect on the power system.

Line outage data were gathered from [8] for the twenty-three lines contingencies with varying degree of adverse effect on the system operation. The availability of each of these lines is calculated using (7). Contingency state probabilities are computed as in (8). Probabilistic performance index for $\mathrm{N}-1$ contingency is computed as in (9). The results are given in Table II.

The ranking of the contingencies using overall performance index (PI) and probabilistic performance index (PPIN-1) are given in Table III.

\section{CONCLUSION}

The commonly used method of ranking transmission line contingencies using the active power performance index, the voltage performance index or the overall performance index will rank the contingencies based on their severity on the power system security only. A better ranking index, that takes into consideration both system security and reliability is the probabilistic performance index. This index has been developed in this work for the ranking of $\mathrm{N}-1$ contingencies and demonstrated in ranking the transmission line contingencies on the Nigerian National Electrical Power System. The possible line contingencies were first screened using Newton Raphson method to determine their severity on the network. It was discovered that the outage of sixteen out of the forty-one lines leads to unacceptable bus voltage levels (instability) in the system showing that the system is overstretched or overloaded. The remaining twenty-three possible line contingencies leads to varying degrees of adverse effect on the network. Simulation results also revealed that, apart from the outages that results in system instability, the next most dangerous contingency based on its effect on the security of the power system is the disconnection of the line from Shiroro TS to Katampe and the outage of the line between Oshogbo and Egbin TS is the least severe. Based on the probabilistic index, the most severe contingency, which is the one that should receive more attention to ensure both secured and reliable operation of the power system, is the outage of the line from Gamno to Jebba TS while the outage of Egbin TS to Aja line is the least severe. All the line outages have been ranked according to the power performance index (PI) and the probabilistic performance index for $\mathrm{N}-1$ contingencies (PPIN$1)$. 
TABLE I: CONTINGENCY SCREENING

\begin{tabular}{|c|c|c|c|c|}
\hline S/No. & $\begin{array}{c}\text { Line on Outage } \\
\text { Bus to Bus }\end{array}$ & $\begin{array}{c}\text { Active Power Performance } \\
\text { Index }\left(\mathrm{PI}_{\mathrm{P}}\right)\end{array}$ & $\begin{array}{l}\text { Voltage Performance Index } \\
\left(\mathrm{PI}_{\mathrm{V}}\right)\end{array}$ & $\begin{array}{l}\text { Overall Performance Index } \\
(\mathrm{PI})\end{array}$ \\
\hline 1 & (1) (10) & 0.6634 & 0.7146 & 1.3780 \\
\hline 2 & (1) (30) & 0.5994 & 0.7170 & 1.3164 \\
\hline 3 & (2) (25) & 0.5856 & 0.7044 & 1.2900 \\
\hline 4 & (4) (25) & 0.5855 & 0.7029 & 1.2884 \\
\hline 5 & (6) (14) & & Causes unacceptable bus voltage levels & \\
\hline 6 & (6) (12) & & Causes unacceptable bus voltage levels & \\
\hline 7 & (31) (15) & 0.6124 & 0.816 & 1.4284 \\
\hline 8 & (8) (31) & 0.6390 & 0.7738 & 1.4128 \\
\hline 9 & (31) (20) & 0.5921 & 0.9023 & 1.4944 \\
\hline 10 & (9) (23) & & Causes unacceptable bus voltage levels & \\
\hline 11 & (11) (12) & 0.5875 & 0.7041 & 1.2916 \\
\hline 12 & (11) (22) & 0.5878 & 0.7031 & 1.2909 \\
\hline 13 & (11) (10) & 0.5850 & 0.7034 & 1.2884 \\
\hline 14 & (11) (32) & 0.5889 & 0.7050 & 1.2939 \\
\hline 15 & (22) (23) & & Causes unacceptable bus voltage levels & \\
\hline 16 & (22) (4) & 0.5854 & 0.7062 & 1.2916 \\
\hline 17 & (22) (26) & & Causes unacceptable bus voltage levels & \\
\hline 18 & (22) (2) & 0.5851 & 0.7037 & 1.2888 \\
\hline 19 & (10) (22) & 0.5904 & 0.7036 & 1.2940 \\
\hline 20 & (21) (11) & 0.5970 & 0.7117 & 1.3087 \\
\hline 21 & (21) (10) & 0.5850 & 0.7068 & 1.2918 \\
\hline 22 & (17) (24) & & Causes unacceptable bus voltage levels & \\
\hline 23 & (17) (18) & & Causes unacceptable bus voltage levels & \\
\hline 24 & $(26)(28)$ & & Causes unacceptable bus voltage levels & \\
\hline 25 & (26) (27) & & Causes unacceptable bus voltage levels & \\
\hline 26 & (26) (3) & & Causes unacceptable bus voltage levels & \\
\hline 27 & (18) (19) & & Causes unacceptable bus voltage levels & \\
\hline 28 & (30) (13) & 0.5859 & 0.7037 & 1.2896 \\
\hline 29 & (18) (33) & & Causes unacceptable bus voltage levels & \\
\hline 30 & $(28) \quad(5)$ & & Causes unacceptable bus voltage levels & \\
\hline 31 & (32) (12) & 0.6101 & 0.7044 & 1.3145 \\
\hline 32 & (7) (12) & & Causes unacceptable bus voltage levels & \\
\hline 33 & (15) (16) & & Causes unacceptable bus voltage levels & \\
\hline 34 & (15) (17) & & Causes unacceptable bus voltage levels & \\
\hline 35 & (11) (30) & 0.5849 & 0.7033 & 1.2882 \\
\hline 36 & (32) (30) & 0.5880 & 0.7031 & 1.2911 \\
\hline 37 & (8) (30) & & Causes unacceptable bus voltage levels & \\
\hline 38 & (15) & 0.6010 & 0.8357 & 1.4367 \\
\hline 39 & $(20)$ & 0.5769 & 0.7712 & 1.3481 \\
\hline 40 & (1) (13) & 0.5853 & 0.7040 & 1.2893 \\
\hline 41 & (10) (29) & & Causes unacceptable bus voltage levels & \\
\hline
\end{tabular}

TABLE II: PPIN-1 For Contingencies That Do NOT CAUSE UnACCEPTABLE VOLTAGE LEVEL

\begin{tabular}{|c|c|c|c|c|c|c|c|c|}
\hline S/No. & $\begin{array}{r}\text { Line } \\
\text { Bus }\end{array}$ & $\begin{array}{l}\text { atage } \\
\text { Bus } \\
\end{array}$ & $\begin{array}{l}\text { Availability } \\
(\text { av })_{\mathrm{k}}\end{array}$ & $\begin{array}{c}\text { Contingency state } \\
\text { probability }\left(\mathrm{P}_{\mathrm{j}}\right)\end{array}$ & $\begin{array}{c}\text { Active power } \\
\text { performance index }\left(\mathrm{PI}_{\mathrm{P}}\right)\end{array}$ & $\begin{array}{c}\text { Voltage Performance } \\
\text { index }\left(\mathrm{PI}_{\mathrm{V}}\right)\end{array}$ & $\begin{array}{c}\text { Overall Performance } \\
\text { index }(\mathrm{PI})\end{array}$ & PPIN-1 \\
\hline 1 & (1) & (10) & 0.909 & 0.0331 & 0.6634 & 0.7146 & 1.3780 & 0.0456 \\
\hline 2 & (1) & (30) & 0.952 & 0.0167 & 0.5994 & 0.7170 & 1.3164 & 0.0220 \\
\hline 3 & (2) & (25) & 0.956 & 0.0152 & 0.5856 & 0.7044 & 1.2900 & 0.0196 \\
\hline 4 & (4) & (25) & 0.970 & 0.0102 & 0.5855 & 0.7029 & 1.2884 & 0.0131 \\
\hline 5 & (31) & (15) & 0.945 & 0.0193 & 0.6124 & 0.8160 & 1.4284 & 0.0276 \\
\hline 6 & (8) & (31) & 0.942 & 0.0204 & 0.6390 & 0.7738 & 1.4128 & 0.0288 \\
\hline 7 & (31) & (20) & 0.969 & 0.0106 & 0.5921 & 0.9023 & 1.4944 & 0.0158 \\
\hline 8 & (11) & (12) & 0.914 & 0.0311 & 0.5875 & 0.7041 & 1.2916 & 0.0402 \\
\hline 9 & (11) & (22) & 0.953 & 0.0163 & 0.5878 & 0.7031 & 1.2909 & 0.0210 \\
\hline 10 & (11) & (10) & 0.976 & 0.0081 & 0.5850 & 0.7034 & 1.2884 & 0.0104 \\
\hline 11 & (11) & (32) & 0.941 & 0.0207 & 0.5889 & 0.7050 & 1.2939 & 0.0268 \\
\hline 12 & (22) & (4) & 0.943 & 0.0200 & 0.5854 & 0.7062 & 1.2916 & 0.0258 \\
\hline 13 & (22) & (2) & 0.932 & 0.0241 & 0.5851 & 0.7037 & 1.2888 & 0.0311 \\
\hline 14 & (10) & (22) & 0.943 & 0.0200 & 0.5904 & 0.7036 & 1.2940 & 0.0259 \\
\hline 15 & (21) & (11) & 0.988 & 0.0040 & 0.5970 & 0.7117 & 1.3087 & 0.0052 \\
\hline 16 & (21) & (10) & 0.941 & 0.0207 & 0.5850 & 0.7068 & 1.2918 & 0.0267 \\
\hline 17 & (30) & (13) & 0.988 & 0.0040 & 0.5859 & 0.7037 & 1.2896 & 0.0052 \\
\hline 18 & (32) & (12) & 0.902 & 0.0359 & 0.6101 & 0.7044 & 1.3145 & 0.0472 \\
\hline 19 & (11) & (30) & 0.983 & 0.0057 & 0.5849 & 0.7033 & 1.2882 & 0.0073 \\
\hline 20 & (32) & (30) & 0.984 & 0.0054 & 0.5880 & 0.7031 & 1.2911 & 0.0070 \\
\hline 21 & (8) & (15) & 0.954 & 0.0160 & 0.6010 & 0.8357 & 1.4367 & 0.0230 \\
\hline 22 & (8) & (20) & 0.969 & 0.0106 & 0.5769 & 0.7712 & 1.3481 & 0.0143 \\
\hline 23 & (1) & (13) & 0.973 & 0.0092 & 0.5853 & 0.7040 & 1.2893 & 0.0119 \\
\hline
\end{tabular}


TABLE III: CONTINGENCIES RANKED ACCORDING TO PI AND PPIN-1

\begin{tabular}{|c|c|c|c|c|c|c|c|}
\hline \multicolumn{4}{|c|}{ Ranking based on PI } & \multicolumn{4}{|c|}{ Ranking based on PPIN-1 } \\
\hline \multirow{2}{*}{$\begin{array}{c}\text { Ranking } \\
1\end{array}$} & \multicolumn{2}{|c|}{$\begin{array}{c}\text { Line on outage } \\
\text { Bus to Bus }\end{array}$} & \multirow{2}{*}{$\begin{array}{c}\text { PI } \\
1.4944\end{array}$} & \multirow{2}{*}{$\begin{array}{c}\text { Ranking } \\
1\end{array}$} & \multicolumn{2}{|c|}{$\begin{array}{c}\text { Line on outage } \\
\text { Bus to Bus }\end{array}$} & \multirow{2}{*}{$\begin{array}{l}\text { PPIN-1 } \\
0.0472\end{array}$} \\
\hline & $(31)$ & $(20)$ & & & $(32)$ & (12) & \\
\hline 2 & (8) & (15) & 1.4367 & 2 & (1) & (10) & 0.0456 \\
\hline 3 & (31) & (15) & 1.4284 & 3 & (11) & (12) & 0.0402 \\
\hline 4 & $(8)$ & $(31)$ & 1.4128 & 4 & $(22)$ & (2) & 0.0311 \\
\hline 5 & (1) & (10) & 1.378 & 5 & (8) & (31) & 0.0288 \\
\hline 6 & (8) & $(20)$ & 1.3481 & 6 & $(31)$ & (15) & 0.0276 \\
\hline 7 & (1) & $(30)$ & 1.3164 & 7 & (11) & (32) & 0.0268 \\
\hline 8 & $(32)$ & (12) & 1.3145 & 8 & $(21)$ & (10) & 0.0267 \\
\hline 9 & $(21)$ & (11) & 1.3087 & 9 & (10) & (22) & 0.0259 \\
\hline 10 & (10) & $(22)$ & 1.2940 & 10 & $(22)$ & (4) & 0.0258 \\
\hline 11 & $(11)$ & $(32)$ & 1.2939 & 11 & $(8)$ & (15) & 0.0230 \\
\hline 12 & $(21)$ & (10) & 1.2918 & 12 & (1) & (30) & 0.0220 \\
\hline 13 & $(22)$ & (4) & 1.2916 & 13 & (11) & (22) & 0.0210 \\
\hline 14 & (11) & (12) & 1.2916 & 14 & (2) & (25) & 0.0196 \\
\hline 15 & $(32)$ & $(30)$ & 1.2911 & 15 & $(31)$ & (20) & 0.0158 \\
\hline 16 & (11) & $(22)$ & 1.2909 & 16 & $(8)$ & (20) & 0.0143 \\
\hline 17 & (2) & $(25)$ & 1.2900 & 17 & (4) & (25) & 0.0131 \\
\hline 18 & $(30)$ & (13) & 1.2896 & 18 & (1) & (13) & 0.0119 \\
\hline 19 & (1) & (13) & 1.2893 & 19 & (11) & (10) & 0.0104 \\
\hline 20 & $(22)$ & (2) & 1.2888 & 20 & (11) & (30) & 0.0073 \\
\hline 21 & (4) & $(25)$ & 1.2884 & 21 & $(32)$ & (30) & 0.0070 \\
\hline 22 & (11) & $(10)$ & 1.2884 & 22 & $(21)$ & (11) & 0.0052 \\
\hline 23 & $(11)$ & $(30)$ & 1.2882 & 23 & $(30)$ & (13) & 0.0052 \\
\hline
\end{tabular}

APPENDIX

TABLE A1: BUS DATA EXPRESED IN PER UNIT ON 330KV, 100MVA BASE

\begin{tabular}{|c|c|c|c|c|c|c|c|}
\hline \multirow{2}{*}{$\begin{array}{c}\text { Bus } \\
\text { Number }\end{array}$} & \multirow[t]{2}{*}{ Bus Name } & \multicolumn{2}{|c|}{ Generation } & \multicolumn{2}{|c|}{ Load } & \multirow{2}{*}{$\begin{array}{c}\text { Voltage } \\
\text { Magnitude (pu) }\end{array}$} & \multirow{2}{*}{$\begin{array}{c}\text { Voltage Angle } \\
\text { (Radians) }\end{array}$} \\
\hline & & $\mathrm{P}(\mathrm{pu})$ & $\mathrm{Q}(\mathrm{pu})$ & $\mathrm{P}(\mathrm{pu})$ & $\mathrm{Q}(\mathrm{pu})$ & & \\
\hline 1 & Egbin & & & & & 1.0 & 0.0 \\
\hline 2 & Delta GS & 0.550 & & & & 1.0 & \\
\hline 3 & Okpai GS & 2.200 & & & & 1.0 & \\
\hline 4 & Sapele GS & 0.750 & & & & 1.0 & \\
\hline 5 & Afam GS & 4.790 & & & & 1.0 & \\
\hline 6 & Kainji GS & 3.230 & & & & 1.0 & \\
\hline 7 & Jebba GS & 3.220 & & & & 1.0 & \\
\hline 8 & Shiroro GS & 2.800 & & & & 1.0 & \\
\hline 9 & Geregu GS & 2.000 & & & & & \\
\hline 10 & Ikeja-West & & & 3.341 & 3.825 & & \\
\hline 11 & Oshogbo & & & 1.781 & 1.103 & & \\
\hline 12 & Jebba TS & & & 0.224 & 0.003 & & \\
\hline 13 & Aja & & & 1.199 & 0.615 & & \\
\hline 14 & Birnin-Kebbi & & & 2.130 & 1.401 & & \\
\hline 15 & Kaduna & & & 1.080 & 1.487 & & \\
\hline 16 & Kano & & & 2.580 & 1.907 & & \\
\hline 17 & Jos & & & 1.470 & 0.911 & & \\
\hline 18 & Gombe & & & 1.230 & 0.356 & & \\
\hline 19 & Yola & & & 1.120 & 0.540 & & \\
\hline 20 & Katampe & & & 3.110 & 2.333 & & \\
\hline 21 & Aiyede & & & 2.040 & 0.376 & & \\
\hline 22 & Benin & & & 1.660 & 1.554 & & \\
\hline 23 & Ajaokuta & & & 0.400 & 0.090 & & \\
\hline 24 & Makurdi & & & 0.730 & 0.374 & & \\
\hline 25 & Aladja & & & 1.250 & 0.879 & & \\
\hline 26 & Onitsha & & & 1.930 & 1.448 & & \\
\hline 27 & New Haven & & & 1.820 & 1.365 & & \\
\hline 28 & Alaoji & & & 2.760 & 2.070 & & \\
\hline 29 & Akangba & & & 3.690 & 2.767 & & \\
\hline 30 & Egbin TS & & & 2.200 & 1.650 & & \\
\hline 31 & Shiroro TS & & & 0.800 & 0.375 & & \\
\hline 32 & Gamno & & & 0.270 & 0.130 & & \\
\hline 33 & Maiduguri & & & 0.610 & 0.689 & & \\
\hline
\end{tabular}


TABLE A2: LINE DATA EXPRESSED IN PER UNIT ON 330KV, 100MVA BASE

\begin{tabular}{|c|c|c|c|c|c|}
\hline $\begin{array}{c}\text { Line } \\
\text { Number }\end{array}$ & \multicolumn{2}{|c|}{ Line Between } & Length (km) & Impedance (pu) & $\begin{array}{l}\text { Half Line Charging } \\
\text { Susceptance (pu) }\end{array}$ \\
\hline 1 & (1) Egbin GS & (10) Ikeja West & 62 & $0.0029+0.0241 \mathrm{i}$ & 0.0109 \\
\hline 2 & (1) Egbin GS & (30) Egbin TS & 5 & $0.0005+0.0043 \mathrm{i}$ & 0.0019 \\
\hline 3 & (2) Delta GS & (25) Aladja & 32 & $0.0015+0.0124$ & 0.0056 \\
\hline 4 & (4) Sapele gs & (25) Aladja & 63 & $0.0029+0.0245 i$ & 0.0111 \\
\hline 5 & (6) Kainji GS & (14) B.Kebbi & 310 & $0.0145+0.1205 \mathrm{i}$ & 0.0545 \\
\hline 6 & (6) Kainji GS & (12) JebbaTS & 81 & $0.0038+0.0315 \mathrm{i}$ & 0.0142 \\
\hline 7 & (31) Shiroro TS & (15) Kaduna & 96 & $0.0045+0.0373 \mathrm{i}$ & 0.0169 \\
\hline 8 & (8) Shiroro GS & (31) ShiroroTS & 8 & $0.0007+0.0054 \mathrm{i}$ & 0.0025 \\
\hline 9 & (31) Shiroro TS & (20) Katampe & 144 & $0.0067+0.0560 \mathrm{i}$ & 0.0253 \\
\hline 10 & (9) Geregu GS & (23) Ajaokuta & 5 & $0.0007+0.0062 \mathrm{i}$ & 0.0028 \\
\hline 11 & (11) Oshogbo & (12) JebbaTS & 157 & $0.0073+0.0610 \mathrm{i}$ & 0.0276 \\
\hline 12 & (11) Oshogbo & (22) Benin & 251 & $0.0117+0.0976 \mathrm{i}$ & 0.0441 \\
\hline 13 & (11) Oshogbo & (10) IkejaWest & 252 & $0.0118+0.0980 \mathrm{i}$ & 0.0443 \\
\hline 14 & (11) Oshogbo & (32) Gamno & 75 & $0.0035+0.0292 \mathrm{i}$ & 0.0132 \\
\hline 15 & (22) Benin & (23) Ajaokuta & 195 & $0.0091+0.0758 \mathrm{i}$ & 0.0343 \\
\hline 16 & (22) Benin & (4) Sapele GS & 50 & $0.0023+0.0194 \mathrm{i}$ & 0.0088 \\
\hline 17 & (22) Benin & (26) Onitsha & 137 & $0.0064+0.0533 \mathrm{i}$ & 0.0241 \\
\hline 18 & (22) Benin & (2) Delta GS & 107 & $0.0050+0.0416 \mathrm{i}$ & 0.0188 \\
\hline 19 & (10) IkejaWest & (22) Benin & 280 & $0.0131+0.1088 \mathrm{i}$ & 0.0492 \\
\hline 20 & (21) Ayede & (11) Oshogbo & 115 & $0.0054+0.0447 \mathrm{i}$ & 0.0202 \\
\hline 21 & (21) Ayede & (10) Ikeja West & 137 & $0.0064+0.0533 \mathrm{i}$ & 0.0241 \\
\hline 22 & (17) Jos & (24) Makurdi & 247 & $0.0116+0.0960 \mathrm{i}$ & 0.0434 \\
\hline 23 & (17) Jos & (18) Gombe & 264 & $0.0123+0.1026 \mathrm{i}$ & 0.0464 \\
\hline 24 & (26) Onitsha & (28) Alaoji & 138 & $0.0065+0.0536 \mathrm{i}$ & 0.0243 \\
\hline 25 & (26) Onitsha & (27) N.Heaven & 96 & $0.0045+0.0373 \mathrm{i}$ & 0.0169 \\
\hline 26 & (26) Onitsha & (3) Okpai & 80 & $0.0037+0.0311 \mathrm{i}$ & 0.0141 \\
\hline 27 & (18) Gombe & (19) Yola & 188 & $0.0088+0.0731 \mathrm{i}$ & 0.0331 \\
\hline 28 & (30) EgbinTS & (13) Aja & 28 & $0.0013+0.0109 \mathrm{i}$ & 0.0049 \\
\hline 29 & (18) Gombe & (33) Maiduguri & 278 & $0.0130+0.1081 \mathrm{i}$ & 0.0489 \\
\hline 30 & (28) Alaoji & (5) Afam GS & 25 & $0.0012+0.0097 \mathrm{i}$ & 0.0044 \\
\hline 31 & (32) Gamno & (12) Jebba TS & 80 & $0.0037+0.0311 \mathrm{i}$ & 0.0141 \\
\hline 32 & (7) JebbaTS & (12) Jebba GS & 8 & $0.0005+0.0039 \mathrm{i}$ & 0.0018 \\
\hline 33 & (15) Kaduna & (16) Kano & 230 & $0.0108+0.0894$ & 0.0404 \\
\hline 34 & (15) Kaduna & (17) Jos & 196 & $0.0092+0.0762 \mathrm{i}$ & 0.0345 \\
\hline 35 & (11) Oshogbo & (30) Egbin TS & 157 & $0.0073+0.0610$ & 0.0276 \\
\hline 36 & (32) Gamno & (30)Egbin TS & 80 & $0.0037+0.0311$ & 0.0141 \\
\hline 37 & (8) Shiroro GS & (30) Egbin TS & 244 & $0.0114+0.0948$ & 0.0429 \\
\hline 38 & (8) Shiroro GS & (15) Kaduna & 96 & $0.0045+0.0373$ & 0.0169 \\
\hline 39 & (8) Shiroro GS & (20) Katampe & 218 & $0.0102+0.0847$ & 0.0383 \\
\hline 40 & (1)Egbin GS & (13) Aja & 14 & $0.0007+0.0054$ & 0.0025 \\
\hline 41 & (10) Ikeja West & (29) Akangba & 17 & $0.0008+0.0066$ & 0.0030 \\
\hline
\end{tabular}




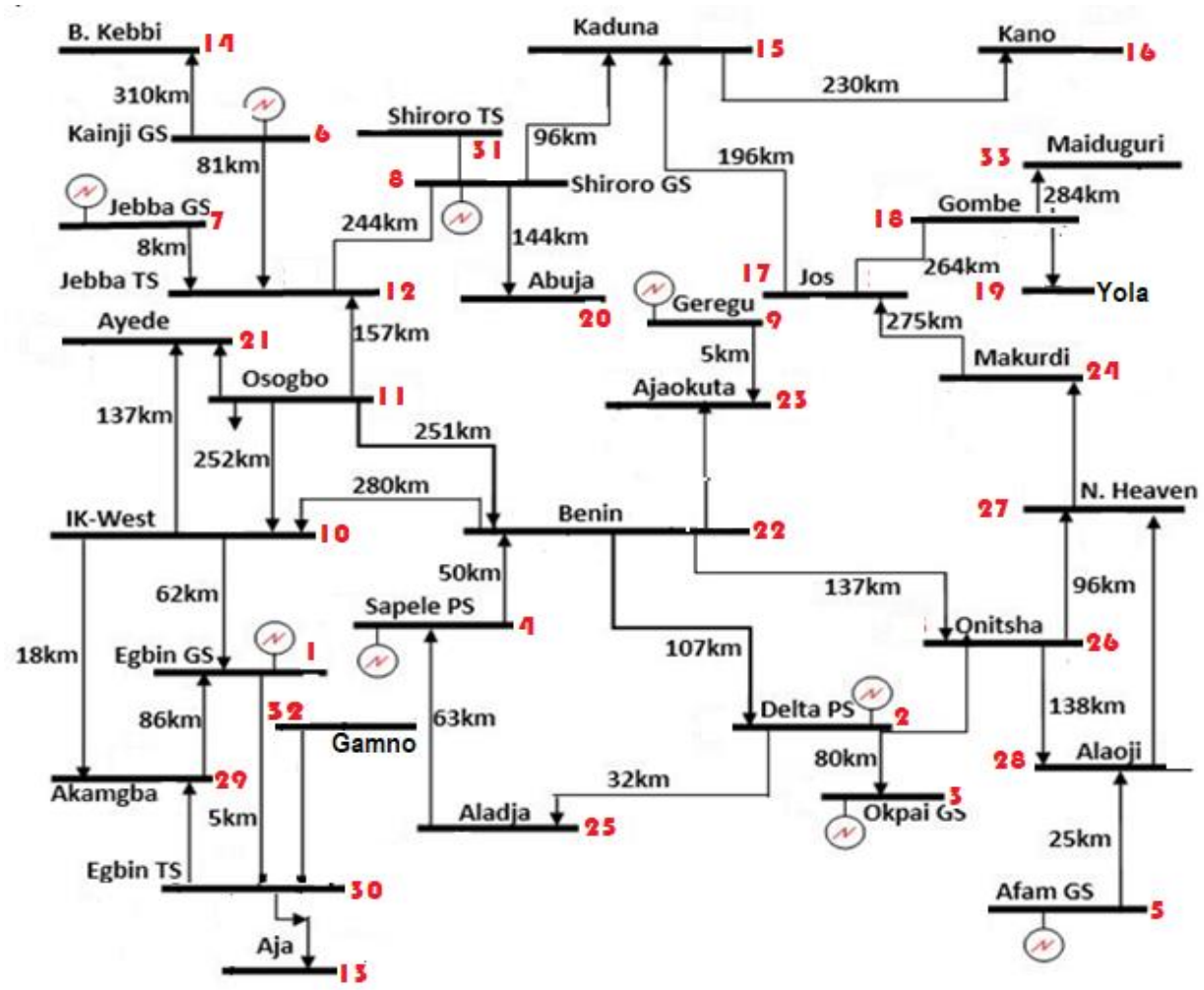

Fig. A1: Single line diagram of the 32 bus Nigeria National Electrical Power System.

\section{REFERENCES}

[1] Pritirekha Naik, "Power System Contingency Ranking Using Newton Raphson Load Flow Method and Its Prediction Using Soft Computing Techniques" Master of Technology in Industrial Electronics Thesis, Department of Electrical Engineering, National Institute of Technology, Rourkela. India, 2014.

[2] Ramasamy Natarajan, "Computer-Aided Power System Analysis" Practical Power Associates Raleigh, North Carolina, U.S.A. 2002.

[3] Ali Abdulwahhab Abdulrazzaq, "Contingency Ranking of Power Systems Using a Performance Index" International Research Journal of Engineering and Technology (IRJET), 2015, vol. 2. no. 2, pp. 180-183.

[4] Amit Kumar Roy and Sanjay Kumar Jain, "Improved Transmission Line Contingency Analysis in Power System Using Fast Decoupled Load Flow" International Journal of Advances in Engineering \& Technology, 2013, vol. 6, issue 5, pp. 2159-2170.

[5] Ummidi Sirisha, M Sobha and Arun Kumar Ch, "Power System Contingency Analysis by using Voltage and Active Power Performance Index", International Journal for Modern Trends in Science and Technology, July 2020, vol. 06, issue 07, pp. 52-60; https://doi.org/10.46501/IJMTST060708.

[6] Abdullah M. Al-Shaalan, "Contingency Selection and Ranking for Composite Power System Reliability Evaluation" Journal of King Saud University - Engineering Sciences, 2020, Vol. 32, pp. 141-147.

[7] Venkata Satheesh Babu K., Madhusudan V. and Ganesh V, "Probabilistic Performance Index Based Contingency Screening for Composite Power System Reliability Evaluation” International Journal of Electrical and Computer Engineering (IJECE), 2018, vol. 8, no. 5, pp. 2661-2670.

[8] Transmission Company of Nigeria (2019), Generation and Transmission Grid Operations (Annual Technical Report) for the year 2018.

[9] R. C. Okonkwo, "Thermal Power Stations Reliability Evaluation in a Hydrothermal System” Nigerian Journal of Technology, 1997, vol. 18, no. 1 , pp. 42-49.

[10] S. O. Okozi, P.C Chukwudi, M. Olubiwe and K.C Obute, "Reliability Assessment of Nigerian Power Systems Case Study of 330kv Transmission Lines in Benin Sub - Region". International Journal of Engineering Research \& Technology (IJERT), 2018, vol. 7, issue 03, pp.399-405.

[11] David Elmakias (Ed.), "New Computational Methods in Power System Reliability”. (2008), Chapter 2, pp. 55-166, Springer. 